\title{
Obituary \\ Professor J. W. G. Porter, M.A., Ph.D. (Cantab.), F.I.Biol.
}

Joseph William Geoffrey Porter, Director of the National Institute for Research in Dairying, died suddenly on 17 November 1983 at the age of 63.

Geoffrey Porter made his career at the National Institute for Research in Dairying. He joined the Nutrition Department of the Institute in 1945, and succeeded Professor S. K. Kon as its Head in 1965. In 1978 he was appointed Director of the Institute and Consultant Director of the Commonwealth Bureau of Dairy Science and Technology, and the University of Reading conferred upon him the personal title of Research Professor.

He entered Emmanuel College, Cambridge, as an Exhibitioner in 1939, graduating with 1st Class Honours in the Natural Science Tripos in 1941-2. He was then elected a Research Scholar and undertook postgraduate studies into compounds of possible therapeutic interest, under the supervision of Dr F. G. Mann, FRS, in the Department of Organic Chemistry. He was awarded the degree of Ph.D. in 1945.

His early research at the National Institute for Research in Dairying was into the requirements of rats and ruminants for the vitamin $B$ complex and the synthesis of these compounds by the microorganisms of the gut. Of particular interest were investigations on the synthesis of vitamin $B_{12}$ in the rumen and the demonstration of the synthesis of a range of analogues that had vitamin $B_{12}$ activity for microorganisms but not for higher animals. That work came at a time when studies of fermentation within the rumen were at a critical and exciting stage. With colleagues he proceeded to examine the influence on the growth of pigs and poultry of the inclusion of small amounts of antibiotics in the diet, and the mode of action. Later he studied the digestion and metabolism of carbohydrate and protein in the young calf and pig and developed a more general interest in the nutritive value of proteins, especially those of milk; for several years he headed the Agricultural Research Council group on protein nutrition.

The Nutrition Department under S. K. Kon was internationally renowned and Geoffrey Porter contributed signally to that success. When he became departmental Head he introduced new subjects, putting special emphasis on studies in human nutrition and the output and quality of work was maintained.

He gained for himself international recognition as a nutritional scientist and became closely involved with the activities of the Nutrition Society. He served on its Council from 1977 to 1979, and on its programme committee and editorial board. He contributed as an editor to a number of food and agricultural journals and was a member of several committees concerned with nutrition. The Institute of Biology elected him a Fellow in 1978.

New challenges were provided by his appointment as Director. He sought to introduce radical change in the research programme of the Institute, to give greater emphasis to research into the use as opposed to the production of milk, in recognition of the need for improvement in manufacturing outlets, and he reorganized the Institute on a divisional basis to promote the change. New work specifically on nutritional studies relevant to man was introduced because of the increased public concern with adverse effects of foods. At the same time he worked to strengthen links, 
formal and informal, between the Institute and manufacturing industry, and extended the range of national and international activities to which he contributed. Most notable were his appointment as a Scientific Governor of the British Nutrition Foundation, his Chairmanship of the Nutritional Consultative Panel reporting to the dairy industry, and his Presidency of the International Dairy Federation, Commission ' $F$ '.

Five years is a short period in which to create change on the scale envisaged by Geoffrey Porter, or to judge progress. At a time of transition for the industry which the Institute had served with such great success, he acknowledged that the historic role of the Institute could no longer be sustained and began a process of change that should ensure for the Institute a future as distinguished as its past.

His relaxed and easy manner brought him many friends in this country and overseas and made him an effective contributor to the discussion of difficult and sensitive issues that have become a part of modern life.

$$
\text { J. A. F. ROOK }
$$

As the Journal of Dairy Research is partly owned by the National Institute for Research in Dairying, occasions arose from time to time to consult Geoffrey Porter on matters of general policy. Always he made wise and far-sighted decisions which proved to further the success of the Journal. In addition, whenever an extremely knotty editorial problem seemed insoluble, as an experienced editor himself he was able to suggest a totally unexpected yet eminently satisfactory solution. Discussions with him were enlivened by his witty sense of humour and made pleasant by his warm concern for the Journal. 